\title{
A TALE OF TWO EASTWOODS: ICONOGRAPHIC PERSONAAND RHETORICAL ETHOS IN CLINT EASTWOOD'S "HALFTIME IN AMERICA" AND RNC 2012 ADDRESS
}

\author{
CASEY SCHMitT
}

\begin{abstract}
In 2012, actor-director Clint Eastwood was twice the special focus of attention in America, not for his acting or directing accomplishments but for a pair of uniquely prominent and instantly memorable televised ideological statements. His scripted appearance in atwo-minute Super Bowl XLVI halftime commercial for the Chrysler Group was widely lauded while his address to the Republican National Convention in Tampa, Florida, later that year remains to this day an object of pointed criticism and widespread ridicule. This essay uses sideby-side rhetorical analyses of the two examples-this tale of two Eastwoods-to demonstrate the import of expectation and rhetorical persona in an age of modern, national, and global celebrity. The comparison illustrates how a massively famous speaker whose mediated public image has achieved highly symbolically status may both benefit from and struggle with what I call "iconographic persona." The essay argues thatcelebrity speakers and spokespersons in modern societies must seek congruence between iconographic persona and rhetorical ethos. In Eastwood's case, the expectations and associations met and solidified by the Chrysler ad went unmet in the RNC address, and thus two appeals by the same speaker resulted in two very different receptions. In conversation with Amossy, Halloran, and Butterworth in "connecting" contemporary discussions of rhetoric, celebrity, nationalism, and sport, this essay sheds light on the unique rhetorical position of the celebrity speaker in the political or activist spheres.
\end{abstract}

\section{KEY WORDS}

ethos, rhetoric, Clint Eastwood, iconographic persona, RNC, Halftime in America

In September 2012, actor-director Clint Eastwood responded to questions about his August $30^{\text {th }}$ address to the Republican National Convention in Tampa, Florida, delivered just moments before United States presidential candidate Mitt Romney took the stage to accept his party's nomination. "If somebody's dumb enough to ask me to go to a political convention and say something," Eastwood explained "they're gonna have to take what they get" ("Quoted"). It was a grudging yet defiant acknowledgement that the screen icon's extemporaneous 11-minute 
prosopopoiea-directed at an imaginary Barack Obama ostensibly seated in an empty chair stage left of the speaker's podium - had left viewers confused, bemused, and largely underwhelmed. Indeed, in the wake of Eastwood's infamous performance, satirists reveled in the stammering, seemingly directionless absurdity of the unorthodox address while news writers and pundits were left scratching their heads and asking what those convention organizers who had invited Eastwood in the first place had been thinking.

Yet while we might dismiss Eastwood's RNC address and its rhetorical shortcomings as the mere result of poor planning or incoherent delivery, both can be more fully understood and can provide insight into the role of celebrity rhetoric at large when we consider them alongside Eastwood's proven capacity for rhetorical success. Seven months before the RNC address, for instance, over 100 million television viewers had encountered a different side of Eastwood, also speaking to them directly and likewise encouraging them as American citizens to re-group, re-gather, and re-direct their country. During the halftime commercial break of Super Bowl XLVI, the Chrysler Group premiered a two-minute spot entitled "Halftime in America," narrated by Eastwood and highlighting both the plight and determination of everyday Americans during economic recession. Though not affiliated with any political party, the ad readily echoed the kind of the rallying cries one expects of campaign year convention speeches. Eastwood's scripted monologue-played over a video montage of quintessentially American locations, people at work, and close-ups of American faces-utilized an extended American football metaphor to encourage viewers to focus on "what's ahead," to "come together," and to "come from behind" as America's "second half" was about to begin. It was a locker room speech in epic terms, soaked in patriotism, competitive spirit, and capitalist ideals, and it must have given campaign organizers on both sides of the political spectrum chills of inspiration.

With this essay, I seek to use these two examples-this tale of two Eastwoodsto demonstrate the import of expectation and rhetorical persona in an age of modern, national, and global celebrity. The expectations and associations met and solidified by the Chrysler ad went unmet in the RNC address, and thus two appeals by the same speaker resulted in two very different receptions. When RNC organizers invited Eastwood to speak, they were almost certainly hoping to draw upon the same kind of enthusiasm generated by the Super Bowl ad, almost certainly hoping for the same assertive, gritty, film icon version of Eastwood to take the stage. The audience, too, had been primed to expect the same "tough guy" image, drawn from a career's worth of gunslinging roles like Dirty Harry Callahan, the "Man with No Name," and Unforgiven's William Munny. However else Eastwood's address may have failed to inspire audiences or convey a national urgency to vote a straight Republican ticket, it faltered first and foremost by defying expectations.

In the pages that follow, I use rhetorical criticism as a method to present two close analyses of Clint Eastwood in 2012 and illustrate how a massively famous speaker whose mediated public image has achieved highly symbolic status may both benefit from and struggle with an "iconographic persona." First, in a combined textual and audio/visual analysis, I consider the "Halftime in America" spot and examine how and why the two-minute ad utilized audiences' pre-established associations with Eastwood. Next, I consider Eastwood's muchmaligned RNC address to uncover how it failed to meet audience expectations in the same way. After reading the two examples in detail beside one another, I use the findings to argue that celebrity rhetors in modern national and global societies counter with a unique constraint in their oratorical ventures - that is, such speakers must seek congruence between iconographic persona and rhetorical ethos. I conclude by highlighting some repercussions of this perspective for rhetorical criticism of celebrities and politics in the future. 


\section{Ethos AND ICONOGRAPHIC PeRsona: A TheORETICAL FrameWork}

The advertiser or politician who calls upon a celebrity to speak for any cause is seeking to build an appeal based on the celebrity's public image. Existing work in celebrity studies and persona has documented that celebrities, as especially public presentations of self, have the potential to direct public attention and encourage audience association with products, causes, or events (Brockington; Marsh, Hart, and Tindall; Nownes). Celebrities may function as "Big Citizens," influencing public opinion by stating their own ideas and allegiances for others to follow (Rojek) and, as a "presentational model," they provide a sense of self and selfpresentation that others may mimic and adapt, based upon a feeling of personal intimacy and affiliation with the celebrity's "public private self" (Marshall, "Promotion" 44-45). In many ways, the appeal of a celebrity who speaks publicly resembles the concept of ethos in Aristotelian models of rhetoric and oratory, by which the audience's sense of the speaker contributes to or detracts from the speaker's persuasive power.

Yet the ethos of the celebrity rhetor also functions in a more unique manner, differently from Aristotelian models. Modern celebrity speakers ought, of course, to demonstrate wisdom, virtue, and goodwill - the qualities Aristotle lists as essential to persuasive ethos-but they must also account for and counter with a pre-established image of themselves already at play in popular understandings and discourse. The ethos of massively popular figures is often already pre-judged when their public images have achieved media saturation and their public personas ascribed iconic or symbolic status. The celebrity speaker persuades not only on ethos, but on performance and maintenance of a more "powerfully visible exemplification of persona" (Marshall and Barbour) that the audience already anticipates.

This understanding of ethos also differs slightly from more contemporary concepts of ethos in rhetorical studies. It differs, for instance, from the ethos described by Michael J. Hyde, whereby the persuasive ethos of the rhetor is a collaborative outcome of speaker and audience co-habitation-of sharing, assuming, and enacting the same (or, at least, similar)

understandings of what the world is like and who the speaker is/should be within it. A speaker, like Eastwood, and his/her audience must indeed dwell in the same conceptual spaces, but the modern celebrity rhetor's ethos is often even more solidly pre-determined by the public than is the ethos of other modern speakers. That is, the speaker whose identity has achieved iconographic status may struggle to assert a new or original persona in public rhetoric or performance.

Graeme Turner has identified the special relationship between celebrity and public discourse. Celebrity, Turner writes, is a "discursive effect," whereby the individual's particularly prominent persona is actively negotiated through social interaction and representation (13). As Holmes and Redmond note, celebrity persona "does not reside in the individual: it is constituted discursively, "by the way in which the individual is represented"” (Holmes and Redmond, "Journal" 4). Such persona is not developed merely through the presentation of self in everyday life but also-and, more potently - through public development and definition of who the celebrity individual is and ought to be. Turner argues that "those who have been subject to the representational regime of celebrity are reprocessed and reinvented by it," and that to be "folded into this representational regime-to be 'celebritised'-changes how you are consumed and what you can mean" (13). A "Celebritised" individual has comparably little control of her/his public persona once the wider community has developed a shared concept of that individual and, Turner explains, in order to adhere to persona expectation, the celebrity must often adapt to and enact expectations. There are many potential repercussions but, Turner writes, "At the most pragmatic level, for the individual concerned, their celebrity is a 
commercial property which is fundamental to their career and must be maintained and strategised if they are to continue to benefit from it" (14).

Applying this recognition to rhetorical analysis, I propose that the celebrity orator speaks not only with an embodiment of Aristotelian or contemporary ethos but also with an embodiment of iconographic persona. Iconographic persona is ascribed to celebrities through their portrayal in various media rather than through direct, person-to-person contact with their audiences. It is an extreme form of what John Corner terms "mediated persona" - the public image of an individual, setting expectations for that individual's public performancesattributed to only the most widely known and widely represented celebrity speakers. Over time, representations of such individuals can achieve a symbolic potency in public discourse, and the mere image of the individual or mention of that individual's name can serve as symbolic allusion to concepts, populations, and values. Film celebrities like Clint Eastwood or John Wayne become synecdochic references to American frontier expansion, masculinism, and militarism. Actors like James Stewart or Tom Hanks symbolize, for many, wholesome Americana and niceness, while others, like James Dean, Frank Sinatra, or Samuel L. Jackson, signify rebellious swagger and style. These attributes derive, of course, in part from the words, actions, and roles of the celebrities themselves, but they aggregate with fame and mass media repetition into a symbol of the person both distinct from and inseparable from the actual individual. This phenomenon is not limited to film celebrities, as politicians, religious leaders, indeed any mass mediated public figure may accrue iconographic status in time. Even as Eastwood spoke to the RNC crowd in Tampa, for instance, the candidates themselves countered with, accounted for, embraced, and strove to reject aspects of their publicly asserted personas.

Yet Eastwood is a prime case example. One need never have seen an Eastwood film to know that Eastwood is (supposed to be) rough, gritty, and American. He is the frontiersman, the patriotic soldier, the cop who goes to sometimes violent extremes to enforce justice and get his man. His roles in various Western films make his name a reference to frontier expansion, industry, and Manifest Destiny. His celebrated turns as Dirty Harry make his image a symbol of hard fought justice and no-nonsense audacity. His success as a director makes him a symbol of glory and ingenuity, and his familiar growling voice and assertive personal conduct into his old age makes him an icon of toughness and persistence. This iconographic persona follows the rhetor Eastwood wherever he goes, and Eastwood's rhetoric is at its most effective when it acknowledges this factor and capitalizes on it.

The "Halftime in America" commercial uses the roughness, grittiness, and Americanness of Eastwood as a central node for weaving together its metaphors and allusions to nationalism, sport, nostalgia, and industry. These four perhaps disparate ideas are, of course, already linked in the public imaginary (Aden; Butterworth; Von Burg and Johnson), but placing Eastwood in the central position allows the association of patriotism, nostalgia for an imagined American past, physical competition, and tough-as-nails determination to resonate within the persona of the speaker himself. Chrysler's approach was not based on extolling a product through logical argument but was instead based almost entirely on gleaning sentiment for the brand from the nostalgic sphere of sport and nationalism encapsulated in the iconographic Eastwood persona. "Halftime in America" encouraged a collection of identifications, linking viewer anxieties over recession hardships to the civic and financial struggles of Detroit, Michigan, linking Detroit's perseverance following the 2008/2009 auto company bailouts to American exceptionalism, linking this narrative to the nostalgic and politicised realm of competitive sport through both metaphor and placement within the Super Bowl broadcast, and linking all of this to the central persona of Eastwood, whose connection to Detroit, American 
identity, gritty determination, and competitive spirit are all emphasized in word and image before the Chrysler Group logo ever appears onscreen.

In this way, Eastwood serves as a synecdoche for Americans, for football fans, for hard workers, and for Chrysler's ideals. Eastwood appears as the single representative speaking on behalf of each of these parties and, by extension, the collective whole. After laying out the stakes of "halftime," for instance, and describing the plight of Detroit in third person terms, he shifts markedly to the first person singular, noting, "I've seen a lot of tough eras, a lot of downturns in my life," before shifting to the plural, using the words "we," "our," and "us" seventeen times in the ad's subsequent 70 seconds. The strategic effort to encourage consubstantiality-to imply that viewers, Eastwood, Americans, and Chrysler are already substantially one with each other, with special rapport and communal interests (Burke 46)—is plain.

This strategy is by no means new to advertising. In fact, as Sonja K. Foss has noted, Chrysler itself used the exact same strategy following its 1980 bailout under President Carter. Yet even among other advertisements, the "Halftime in America" spot remains a particularly rich case for exploring the role of spokesperson persona and rhetorical ethos. Its simultaneous presentation of collective national ideals and a single, iconographic individual supports Hyde and Smith's assertions that persuasive appeals to ethos build not from the qualities, actions, or art of the rhetor alone, but from communally arrived at understandings shared by and developed in discursive exchange. That is, with this case, we can trace how Aristotle's persuasion "through character," the "most authoritative form of persuasion" (1356a), is achieved through the rhetor's embodiment of presupposed audience understandings of the rhetor him/herself.

Those individuals who have accrued particular fame and celebrity in mass media societies thus face a special rhetorical challenge. Whereas rhetors of the classical era or less famed rhetors in the current day may engage their audiences directly and develop their public personas through immediate discourse, modern celebrity rhetors may find their ethos to be always already solidly defined. Amossy posits that celebrities simultaneously represent their "authentic" selves and the "well-known patterns" of common representation, that "The image of the star is neither the real person nor a fictive character: it is a hybrid pertaining to both" ("Autobiographies" 677). The real person is a continuation of the "fictive character," the pregnant ideograph that shares the individual's name. Thus, the audience who sees and hears Clint Eastwood also simultaneously hears and sees $<$ Clint Eastwood $>$, the iconographic persona associated with Dirty Harry and spaghetti westerns. The two, as Baudrillard would say, are inseparable.

All of this is a roundabout way of explaining why the combination of sporting atmosphere, American identity, the Chrysler Group, and Clint Eastwood should work rhetorically, and why comedic jabs, partisan politics, and the same celebrity speaker should not. The following close analysis of the two examples side by side helps reveal how Eastwood's persona influences the meaning of his rhetoric.

\section{"HALFTIME IN AMERICA:" The GuTTURAL “YeAH” OF RUgGed AuTHORITY}

Chrysler's halftime commercial is striking in the way it focuses attention on Eastwood in spite of its grand, national scope. Yes, it features images of dozens of individual Americans, at home and at work, in cities and in towns, but only Eastwood speaks during the full two minutes. Yes, he uses the term "we" throughout, but his explicit use of the first person singular at the 39second mark places his experience in special privilege, making him a unique representative of 
the nation as a whole. The production and direction of the commercial directed attention to Eastwood as the central figure, capitalizing on his ethos from beginning to end.

This direction of attention to Eastwood as an individual begins, in fact, in the advertisement's very first moments. Aired immediately after the Super Bowl halftime show-a musical performance featuring hundreds of dancers and a stadium full of cheering fans"Halftime in America's" first shot features the image of a lone silhouetted figure walking through a dark stadium exit as the roar of the crowd quiets to a hush and the narrator's voice takes over. In the moment of airtime, this figure could be understood to be stepping out from the crowd in the Super Bowl stadium itself. The figure casts a stark, larger-than-life shadow against a bare brick wall, and the suddenly sombre tone conveys a personal gravity. "It's halftime," says a voice, and the screen fades to black momentarily. In a split-second of video and audio silence, our attention is directed from a stadium full of revellers to a single individual. This figure is Eastwood, of course, but he is kept in darkness, leaving audiences to guess at his identity (though producers were also surely expecting some viewers to quickly recognize the actor's iconic voice). As the ad and its narrative progress, the camera revisits the figure in the exit tunnel as he walks closer and closer to the lens. At the 1-minute, 23-second mark, Eastwood's face is revealed as he steps into the light. It is the last in a series of montage close-ups on individuals, and, indeed, his is the only face visible for the remainder of the piece. The video montage climaxes in its longest extended shot, a 14-second close-up of Eastwood's face, framed from brow to chin, and filling nearly the entire screen as the music once again quiets to a hush. Eastwood is speaking of America, and Detroit, and Chrysler, perhaps, but it is Eastwood, too, who is the focus of attention.

This focus allows Eastwood himself and the ad's producers to draw from the Eastwood persona. It allows for an unspoken association of words and images with those values and ideals already packed into the public concept of the iconographic "Clint Eastwood." In particular, the ad focuses on competitive determination (through allusion to sport and auto industry resilience), to Americanism, to the city of Detroit, and to assertive (if need be, violent) defiance. Each of these themes is thoroughly congruent with the popular Eastwood image.

Following the pause after the announcement that "it's halftime," Eastwood's voiceover narration lays out an explicit connection between football, sporting competitiveness, and national struggle. "Both teams are in their locker room," he says, "discussing what they can do to win this game in the second half. It's halftime in America, too." The image on the screen changes from the figure in the tunnel to an empty porch swing overlooking wooded, rolling hills, and then to a cityscape from above. With the metaphor of sport and nation established, the ad then explicitly likens the struggles of economic recession to the physical strain of athletic competition. Eastwood continues, "People are out of work and they're hurting. And they're all wondering what they're going to do to make a comeback." Social, fiscal, and emotional pain are in this moment likened to the noble stress of sport, a "no pain, no gain" arena with decisive victory over adversity clearly and always in sight. Yet the stakes are also implied to be higher than those of sport as the ad features intimate images of home and family, and an explicit narrated assertion that "we're all scared, because this isn't a game."

In its first 25 seconds, the ad concretely establishes its metaphor of physical struggle, stress, and competition, all readily tied up in the Eastwood persona. Eastwood's most celebrated film role characters take on long odds and corruption through literal, agonistic, life-and-death competition. He is "rugged" (Woodall) and "unyielding" ("Clint"), the "quintessential tough guy" ("'Halftime'") who can "turn vicious if pushed too far" ("Clint"). Film viewers over the years have seen Eastwood suffer pain and strain, grit his teeth, and come out on top. The iconographic 
Eastwood is the champion many viewers would want in their corner when threatened and scared. The script and image themes of agonistic metaphor thus align with the rhetor's public persona.

Next, with the central sporting metaphor established, the ad narrows its focus from "America" at large to the City of Detroit. The Michigan state flag appears in washed out tones, followed by industrial images of the city's foundries and manufacturing lines. Eastwood explains that "the people of Detroit know a little something about this. They almost lost everything," then positions himself as a representative of the city in the first person plural, saying, "but we all pulled together, now Motor City is fighting again." The allusion to physical competition and struggle continues in the words "pulled together" and "fighting." The symbolically ragged, tough, industrious city of Detroit here serves as a clear synecdoche for the nation, and the move anticipates and encourages the synecdochic positioning of the symbolically ragged, tough, and industrious Eastwood as the advertisement moves forward. This move is also anticipated and encouraged by a visual return to the single individual in the tunnel, still in shadows. It is also at this very moment that Eastwood speaks in first person singular and refers to "downturns in [his own] life." The individual speaker is emphasized as a representative of Detroit, and Detroit as a representative of the nation.

This move again emphasizes Eastwood's ethos and draws from his film career persona. Viewers and news outlets around the world acknowledged the import of Eastwood's symbolic relationship to Detroit, established by his role in the 2008 film Gran Torino ("Clint;" Woodall), the story of a retired Ford factory worker, war veteran, and Silver Star recipient living in the run-down Detroit neighbourhood of Highland Park. Eastwood both starred in and directed the film, which was shot in Detroit near the height of the city's economic woes. Though it was Eastwood's most financially successful and critically acclaimed role of the $21^{\text {st }}$ century (Chemi), it is perhaps most well-known for the iconic scene in which a grizzled Eastwood threatens a group of teenage gang members with a rifle and growls, "Get off my lawn." The themes of Detroit's plight, American nationalism, the auto industry, Eastwood's persona, and aggressive struggle against urban and civic decay were already, for many, bound together in the public imagination.

At the advertisement's halfway mark, the words and images shift to a more optimistic, resilient, and forward-looking tone. Clouded skies give way to a series of clear skies and sunlit scenes. Eastwood's words once again evoke the football coach's locker room speech, as he explains, "after those trials, we all rallied around what was right, and acted as one. Because that's what we do. We find a way through tough times, and if we can't find a way, then we'll make one. All that matters now is what's ahead. How do we come from behind? How do we come together? And, how do we win?" Talk of toughness, of making a way for moving ahead (similar to the work of a football team's offensive line), and winning all further cement association of Eastwood's tenacity with physical struggle and sporting victory. Chrysler cars begin to appear in the video montage, and Eastwood's face is finally revealed (at the word "win"). Over the image of an auto assembly line, Eastwood asserts, "Detroit's showing us it can be done. And, what's true about them is true about all of us."

At this point, the audience is primed for Eastwood's final, aggressive, singular appeal. Stepping from the shadows and finally revealing his face, Eastwood builds to a climactic declaration: "This country can't be knocked out with one punch. We get right back up again and when we do the world is going to hear the roar of our engines." The words rally sport fans and patriots while simultaneously recalling the screen Eastwood literally rising from any number of blows in his heroic celluloid exploits, or as grizzled boxing trainer Frankie Dunn in 2004's 
Academy Award winner for Best Picture, Million Dollar Baby. The "roar" of engines is an obvious allusion to automobiles but, after a slight pause, it is also embodied in the speaker himself. "Yeah," Eastwood growls in a deep, guttural, sandpapery tone, "it's halftime America. And our second half is about to begin." The "yeah" is neither articulate nor argumentative, but it punctuates all that precedes it. It is assertive and masculine, demanding attention as the speaker scowls directly at the viewer through the television screen. The advertisement's music swells as if echoing and emulating that roar, or perhaps the roar of a stadium crowd. It symbolizes the roar of literal engines and metaphorical willpower, the nostalgic optimism of sport, and the nonchalant, unwavering confidence of the iconographic Eastwood.

In two minutes' time, football and athleticism, industrial regeneration and automotive industry, American spirit and determination in the face of adversity were all made manifestly consubstantial in the figure of the speaker.

\section{RNC 2012: THE GOOD, THE BAD, AND THE INCONGRUOUS}

By the evening of Monday, February 6, Chrysler's "Halftime in America" ad had over 550,000 views on YouTube (Monroe). Traffic on Twitter and other online sites spiked in reference to and discussion of the spot (Woodall). It was water cooler talk across the nation, and few had missed the ostensibly non-political ad's social and political overtones. While initially lauded online by liberals and conservatives alike, by Monday morning many journalists agreed that the spot read as a celebration of President Obama's handling of the auto bailout ("Clint;" "'Halftime;"' Lee; Monroe). Republican strategist Karl Rove claimed he was "offended" by the ad and its seemingly partisan message ("Clint;" "'Halftime'"). On the other side of the aisle, prolabour liberals condemned the ad's manipulation of labour protest footage (Nichols; Shaw). As the week wore on, Chrysler's Italian CEO Sergio Marchionne and Eastwood himself maintained that the ad was about America and cars, not politics. In a statement to Fox News, Eastwood swore, "There is no spin in that ad. On this I am certain." The New Yorker's Amy Davidson contributed to this sentiment in a February 7 column, writing that the ad was "not about Obama or even, mostly, about Detroit, but about time-in the life of a man, as much as a nation," about "the city and the country, and the lines of Eastwood's face."

Yet the potential for a politically-charged reading remained. Eastwood said to Fox, "I am certainly not politically affiliated with Mr. Obama. It was meant to be a message about job growth and the spirit of America," but added, "If Obama or any other politician wants to run with the spirit of that ad, go for it" (Monroe). Certainly, in a presidential campaign season, both Democrats and Republicans likely considered this advice. Eastwood's persona had proven to be a powerful one-one that might enhance and promote any number of campaigns. As Mike Jackson, CEO of the largest U.S. auto dealership group, wrote on Twitter, Eastwood himself "could get elected president with that ad" (Woodall).

Of course, Eastwood's own political history is a bit complex, not fitting easily into a twoparty binary. He is "a fiscal conservative who takes left-leaning stands on social issues ("Clint"), including gay marriage and environmental protection. He actively supported Republican John McCain in the 2008 U.S. presidential election, but also expressed open admiration for California's Democratic governor, Jerry Brown ("Clint"). He served on the California State Park Commission under Republican governor, Arnold Schwarzenegger, but had supported Schwarzenegger's rival, Democrat Gray Davis, during the 2003 recall election (Monroe).

Ultimately, though, Eastwood's persona does seem to hold particular potential for the contemporary Republican (GOP) platform. From the Reagan years onward, the GOP has often lauded rugged individualism and frontier symbolism. Prominent Republicans in the post- 
Reagan era have often touted their own frontier connections. George W. Bush and Dick Cheney often referenced cowboy ideals and metaphors of Texas frontier justice (West and Carey). John McCain was branded as a "maverick" and his running mate, Sarah Palin, made ample reference to her frontier experiences as Governor and resident of Alaska. Reagan himself, just like Eastwood, first accrued fame as a Hollywood actor, appearing in film Westerns and utilizing an ethos of rugged individualism throughout his political career. Indeed, Reagan acknowledged similarities between himself and Eastwood, and often found opportunities in his political rhetoric to directly quote Eastwood's celebrated line from the 1983 Dirty Harry film, Sudden Impact: "Go ahead, make my day," an aggressive challenge to call any opponent's bluff.

During the Reagan years, Eastwood was a registered Republican, and, like Reagan, transitioned from acting to politics when he served as mayor of the northern California town of Carmel-by-the-Sea from 1986 to 1988. According to campaign chairman and Secretary of State James Baker, Eastwood was "even briefly considered to be a vice presidential possibility" under Reagan's successor, George H.W. Bush (Monroe). His roles as frontiersmen, lawmen, and soldiers associated his name and likeness with American martial strength and justice. And as American $2^{\text {nd }}$ Amendment firearm rights became a more prominent component of the GOP's platform, Eastwood's gun-toting characters became even more iconic. Reagan's celebration of the no-nonsense, stop-at-nothing justice of Dirty Harry Callahan made "Make My Day" a conservative rallying cry, particularly when applied as a nickname to a rise in so-called "Castle Doctrine" laws during the 1980s and 90s, ensuring the legal right of American citizens to use firearms or deadly force against home invaders.

For all these reasons, it seems Clint Eastwood's iconic persona could and would translate to rhetorical potency at the RNC in the same way it had worked to promote American nationalism and cars. Eastwood in 2012 was a registered Libertarian, but in August had officially endorsed Romney for the presidency. In the planning stages-on paper-Eastwood's convention rally speech likely made perfect of sense.

Yet the speech differed significantly from the "Halftime in America" commercial. Whereas Chrysler's ad called upon and affirmed public associations and understandings of Eastwood's iconographic persona, the RNC speech defied them. Rather than stress physical struggle, defiance and strain in noble competition, or the conduct of a trail-worn cowboy, the Eastwood who took the RNC stage was smiling and happy, understated and seemingly, at times, unfocused. He drew not upon a language of grit and tenacity (in fact, at times, actively avoiding this language), but on political philosophy and humour. He mentioned neither Reagan nor the frontier West nor the $2^{\text {nd }}$ Amendment and thus failed to capitalize rhetorically on existing audience identifications. Though pundits criticized the rambling address as ultimately incoherent ("Quoted"), the speech was flawed first and foremost because it was incongruentthat is, Eastwood's onstage ethos lacked the necessary congruence with the iconographic persona that the celebrity rhetor must always counter with and achieve.

If convention and television audiences were not already primed to associate the speaker Eastwood with his iconographic persona, convention organizers directed attention (or, in the words Drake and Higgins, following Erving Goffman, "keyed" attention) with an enormous video screen display. When Eastwood took to the stage, a colossal silhouette of the Man with No Name appeared on the convention screens behind him, along with the sepia-tone image of a Westernstyle ghost town and a few bars of guitar music reminiscent of Ennio Morricone's spaghetti western themes. Then, though the screens reverted to a general red, white, and blue background as the initial applause subsided, a round of convention-goers at stage left greeted Eastwood with chants of "Make My Day!," perhaps in reference to Eastwood's filmic past, and 
perhaps in open reference to Reaganism or gun rights. Eastwood chuckled and opened the speech with a humorous quip, urging the audience to "Save a little for Mitt."

On viewing video of the speech years later, the address begins fairly unremarkably. Eastwood opens with a polite chuckle, a joke, then uses the opportunity to take a few lighthearted jabs at Hollywood Democrats. It is a fair start with the appropriate tone of partisan boosterism. Yet it could have built more from the iconic Eastwood persona. This clean-cut, smiling man clashed with the gunslinger the audience has just moments before been reminded to expect. Eastwood's visible age, used in film and the Chrysler ad to evoke grit and experience, in Tampa signalled, instead, to some, meekness and senility as Eastwood audibly searched for words on a bare stage in the spotlight ("Quoted"). The scowl, shadows, and strain of "Halftime in America" were nowhere in sight.

After its initial remarks, though, the speech takes its most infamous and perhaps damning step. Turning to an empty chair beside him, Eastwood announces he has "Mr. Obama sitting here" and that he is "going to ask him a couple of questions." The focus shifts not to competitive vigour, aggression, and grit, but to a general disappointment with Obama's first term as president. To another speaker at the convention, this strategy would likely work fine. Attacks on Obama and his administrative failures were absolutely fair game. Yet when the celebrity rhetor fails to invoke the ethos that the celebrity icon already conveys, there is communicative dissonance. The two conceptions of the rhetor do not cooperate-do not reinforce and build upon one another-but rather enact an internal struggle within the discursive exchange.

Speaking to the RNC crowd, Eastwood refers to televised images of Obama's 2008 election night victory speech in Grant Park, Chicago. He recalls Oprah Winfrey's televised reaction, crying onscreen, and admits that he was, in fact, crying, too. Again, for another speaker, without a rigidly established public persona built up over decades of direct and indirect representation, this would not be a problem, but for Eastwood, it defies expectations. There is something incongruous about the idea of the Man with No Name shedding tears with Oprah.

Also missing from the speech is the confidence and certainty of the "Halftime" Eastwood ethos. In the RNC address, Eastwood uses qualifiers and halting speech. He says, of Obama, "I was not a big supporter," and of the Obama administration, "I think possibly now it may be time for somebody else to come along." His tone throughout is comparably mellow and restrained. There is no assertive glare, no guttural "yeah."

When, at three and a half minutes into the address, Eastwood turns to the empty chair and speaks to the imaginary Obama, the performance begins to resemble an improvised comedy routine. Eastwood stammers, perhaps miming interruption from his imaginary addressee and perhaps just pausing while he thinks of something to say. Either way, the confident aggression of the iconographic Eastwood is not on display. He is either being exceedingly reserved toward the imaginary president, struggling to talk over an invisible opponent, or ineptly bumbling on the national stage. The bit inspires some laughter from the crowd, but the dissonance remains.

As the bit plays on, Eastwood feigns interruption and allows his imaginary Obama to take the offensive. At one point stammering back against his imaginary guest, Eastwood exclaims, "What? What do you want me to tell Romney? I can't tell him to do that. [He] can't do that to himself! You're crazy, you're absolutely crazy!" Again, laughter ensues at the suggestions that the imaginary Obama would resort to foul language, rudeness, and personal attacks, but the rhetor Eastwood is behaving in a way almost diametrically opposed to the iconic one. In film and in popular imagination, it is Eastwood who acts aggressively, even when fighting on the side 
of right. It is Eastwood who is called "crazy," and threatens "punks" to make his day and get off his lawn. Yet on the RNC stage, Eastwood smirks slightly as he apologizes, "All right, I'm sorry. I can't do that to myself either."

Once the humorous tone is set, the speech functions as a partisan celebration of Republican ideals. When Eastwood turns from the chair and states, more solemnly, "We own this country. We own it. [And it's not] politicians owning it. Politicians are employees of ours," the applause is great and some audience members break into chants of "USA!" It is a rally speech that certainly succeeds in rallying its crowd. But again, and unfortunately, before the speech's conclusion, the dissonance between the humorous, partisan Eastwood and the aggressive, gritty iconographic persona emerges once more. As the crowd takes to its feet, sensing the address is coming to its end, an audience member shouts, "Clint! You made my day!" Eastwood stops midsentence, looks in the shout's direction and, then, turning back to the crowd, explains, "I do not say that word anymore." It is an explicit rejection of his popular persona, and as the crowd becomes more audible, he wavers. He smirks and says, "Well, maybe one last time," but then attempts to steer his focus back to voting matters. The crowd continues to murmur and remains on its feet. Eastwood stops once more and concedes, turning again toward the direction of the shout, and asks, "Okay. You want to make my day?" The crowd applauds heartily and Eastwood presents the phrase for which he may, indeed, be best known, the phrase that has also become a conservative rallying cry in varying situations, as a kind of compromise: "All right," he announces, "I'll start it, you finish it: go ahead ...."

The crowd shouts, "... make my day!" and Eastwood takes his bow, but the dissonance is palpable. Even when explicitly referencing his screen persona for the first time in the entire address, Eastwood actively resists embodying the presupposed image of himself entirely. This resistance hinders the address' rhetorical potential.

\section{CONCLUSIONS}

The special case of celebrities in politics is not a new point of discussion nor a new development in the political sphere (Marshall, Celebrity; Drake \& Higgins), but recognizing the special constraint of ideographic persona does change the approach of rhetorical criticism when analysing celebrity orators in political spaces-especially as celebrity political statements remain one of the most prominent and most widely circulated forms of traditional oratory for rhetorical critics to analyse. Drake and Higgins, for instance, have noted that celebrity and political performance overlap in various ways, but even in their appraisals of varied rhetorical performances by $\mathrm{U} 2$ front man and activist Bono and actor-turned-politician-turned-actor-again Arnold Schwarzenegger, they note that the successful celebrity rhetor "keys" audiences to grant them authority on their subject through the frame of their famed public image and capitalizes on intertextual reference to their non-political careers (97). Public acceptance or public scrutiny of such a speaker is not merely a matter of content, delivery, or political allegiances-it is crucially linked to persona and performance that adheres to (rather than contradicts) popular expectations.

While rhetorical criticism may generally avoid damning a speaker for the things $\mathrm{s} / \mathrm{he}$ did not do, the case of Eastwood's RNC speech makes certain rhetorical elements and strategies palpably absent-especially when considered alongside the Chrysler commercial. The modern rhetor whose image saturates the popular media sphere, whose name and face serve as shorthand for associations and ideas both before and during all of their public actions, must account for this other representation of the self. When the individual aspects of rhetorical ethos of any given discursive moment and those of the intertextual hauntings of iconographic persona 
are compatible, or congruent, they can support one another. The celebrity rhetor can encourage persuasion through the pre-existing identifications of the audience. Conversely, when the ethos of the moment fails to resemble, build from, or fully acknowledge the iconographic persona, the incongruence leads to dissonance and the dissonance opens the speech to potential communicative failure. Where "Halftime in America" succeeded in incorporating Eastwood's existing persona, the RNC address fell short.

I do not mean to suggest that a rhetor with a well-established public image is entirely incapable of changing that image. Any rhetor like Eastwood may certainly aim to alter public conceptions of his/her character, values, or persona-but such efforts require particular rhetorical skill not often required of other less famous or iconic speakers. This is the special burden of the celebrity rhetor. Efforts to counter iconic persona or to play a role different from the one the audience expects must be at least as dynamic, artful, and persuasive as those other representations of the celebrity individual available to the public imagination. Thus, while Eastwood's RNC address functioned to rally an already excited and forgiving crowd, the dissonance caused by the lack of iconographic reference prevented it from succeeding in the same way Eastwood's Chrysler ad had done earlier in the year. In fact, for some audiences, it may have damaged Clint Eastwood's public image, and leaving audiences to potentially now associate the actor not with assertive, optimistic politics, but with a rambling old man arguing with an empty chair (Abdullah).

To some degree, all rhetors must grapple with multiple determinants of ethos and representations of the public self, but in the contemporary, hyper-mediated world, a handful of individuals have achieved something more than a mere public persona. Particularly popular, maligned, or otherwise prominent individuals are defined increasing through their representation in print, in film, online, and elsewhere, and these aggregated representations, when communally shared, continue to define the individual at and during every subsequent moment. Recognition of this additional influence on the context and meaning of celebrity rhetoric will open pathways of critical understanding and analysis of celebrity rhetor methods and strategies.

Celebrity studies and persona studies, as burgeoning fields, are leading the way in this respect (Barbour, Marshall, and Moore), as they "seek to critically understand and to demythologise" celebrities' role in the production of culture" (Holmes and Redmond 2010, 3). Rhetorical critics and analysts may follow their lead to expand beyond assessing traditional forms of ethos and to engage the celebrity rhetor in her/his own right. Moreover, by infusing persona studies with rhetorical criticism and rhetorical criticism with persona studies, future writers can help fill the gap in work on the reception of celebrity by its audience, as noted by Holmes and Redmond $(2010,6)$.

Future rhetorical criticism must trace adherence to and divergence from iconographic persona, skilful translation of celebrity qualities to social or political topics, public image referents not confined to or even explicitly presented in the speech but still present in the public imagination, and the dissonance that occurs when speakers reject their anticipated roles. In spectacular examples of celebrated public address and also in less spectacular instances, this new approach will help us to understand how public image is established, sustained, and challenged, and how the rhetor's interaction with that image shapes the meaning of every single speech. 


\section{WORKS CITED}

Abdullah, Halimah. "Eastwood, the empty chair and the speech everyone's talking about." CNN.com. 31 Aug. 2012. Web. 10 Mar. 2016.

Aden, Roger C. "Nostalgic Communication as Temporal Escape: When It Was a Game's ReConstruction of a Baseball/Work Community." Western Journal of Communication 59.1 (1995): 20-38. Print.

Amossy, Ruth. "Autobiographies of Movie Stars: Presentation of Self and Its Strategies." Poetics Today 7.4 (1986): 673-703. Print.

---. "Ethos at the Crossroads of Disciplines: Rhetoric, Pragmatics, Sociology." Poetics Today 22.1 (2001): 1-23. Print.

Aristotle. On Rhetoric. Trans. George A. Kennedy. New York: Oxford University Press, 2007. Print.

Barbour, Kim, P. David Marshall, and Christopher Moore. "Persona to Persona Studies." M/C Journal: A Journal of Media and Culture 17.3 (2014).

Baudrillard, Jean. Simulations. Trans. Paul Foss, Paul Patton, and Philip Beitchman. New York: Semiotext(e), 1983. Print.

Brockington, Dan. "Towards an International Understanding of the Power of Celebrity Persuasions: A Review and a Research Agenda." Celebrity Studies 6.4 (2015): 486-504. DOI: 10.1080/19392397.2015.1087214

Brummett, Barry, and Margaret Carlisle Duncan. "Theorizing without Totalizing: Specularity and Televised Sports. Quarterly Journal of Speech 76.3 (1990): 227-246. Print.

Burke, Kenneth. A Rhetoric of Motives. Berkeley: University of California Press, 1969. Print.

Butterworth, Michael L. "Militarism and Memorializing at the Pro Football Hall of Fame." Communication and Critical/Cultural Studies 9.3 (2012): 241-258. Print.

Chemi, Eric. "Eastwood's biggest film ever? The bar started low." CNBC.com. 27 Jan. 2015. Web. 10 Mar. 2016.

"Clint Eastwood is Under Fire Over an Advertisement for Bailed-Out Car manufacturer Chrysler." The Australian. 7 Feb. 2012. Web. 7 Feb. 2012.

Corner, John. "Mediated Persona and Political Culture." Media and the Restyling of Politics: Consumerism, Celebrity and Cynicism. Ed. John Corner and Dick Pels. London: Sage, 2003.

Davidson, Amy. “Clint Eastwood's American Halftime." The New Yorker. 7 Feb. 2012. Web. 7 Feb. 2012.

Drake, Philip, and Michael Higgins, Michael. "I'm a Celebrity, Get Me into Politics: The Political Celebrity and the Celebrity Politician." Framing Celebrity: New Directions in Celebrity Culture. Ed. Su Holmes and Sean Redmond. London: Routledge, 2006. Print.

Foss, Sonja K. “Retooling an Image: Chrysler Corporation's Rhetoric of Redemption.” Western Journal of Speech Communication 48.1 (1984): 75-91. Print.

Goffman, Erving. The Presentation of Self in Everyday Life. New York: Doubleday, 1959. Print.

“'Halftime in America; Ad with Clint Eastwood Creates Political Debate." NJ.com. 7 Feb. 2012. Web. 7 Feb. 2012.

Holiday, Judy. “In[ter]vention: Locating Rhetoric's Ethos.” Rhetoric Review 28.4 (2009): 388-405. Print.

Holmes, Su, and Sean Redmond (Eds). Framing Celebrity: New Directions in Celebrity Culture. London: Routledge, 2006.

---. "A Journal in Celebrity Studies." Celebrity Studies 1.1 (2010): 1-10. DOI: 10.1080/19392390903519016

Hyde, Michael J. (Ed.). The Ethos of Rhetoric. Columbia: University of South Carolina Press, 2004. Print.

Lee, M. J. “Clint Eastwood Super Bowl Ad Made Obama's Day, Blogs Say.” Politico. com. 7 Feb. 2012. Web. 7 Feb. 2012. 
Marsh, David, Paul 't Hart, and Karen Tindall. "Celebrity Politics: The Politics of the Late Modernity?" Political Studies Review 8 (2010): 322-340. DOI: 10.1111/j.14789302.2010.00215.x

Marshall, P. David. Celebrity and Power: Fame in Contemporary Culture. Minneapolis: Minnesota University Press, 1997. Print.

---. "The Promotion and Presentation of the Self: Celebrity as Marker of Presentational Media." Celebrity Studies 1.1 (2010): 35-48, DOI: 10.1080/19392390903519057

Marshall, P. David, and Kim Barbour. "Making Intellectual Room for Persona Studies: A New Consciousness and a Shifted Perspective." Persona Studies 1.1 (2015).

Monroe, Bryan. "Were Politics Buried Inside Eastwood's 'Halftime' Commercial?" CNNPolitics.com. 7 Feb. 2012. Web. 7 Feb. 2012.

Nichols, John. "Chrysler Super Bowl Ad Edits Out Wisconsin Union Signs." The Nation. 7 Feb. 2012. Web. 7 Feb. 2012.

Nownes, Anthony J. "An Experimental Investigation of the Effects of Celebrity Support for Political Parties in the United States." American Politics Research 40.3 (2012): 476-500. DOI: $10.1177 / 1532673 X 11429371$

"Quoted: Clint Eastwood Explains Some More About Tampa." The Washington Post. 18 Sept. 2012. Web. 7 Oct. 2012.

Rojek, Chris. "'Big Citizen' Celanthropy and its Discontents." International Journal of Cultural Studies 17.2 (2014): 127-141. DOI: 10.1177/1367877913483422

Shaw, Michael. "Reading the Pictures: The Clint Eastwood Chrysler 'Halftime in America' Controversy, and the Doctored Wisconsin Footage." BagNewsNotes. 7 Feb. 2012. Web. 7 Feb. 2012.

Smith, Craig R. "Ethos Dwells Pervasively: A Hermeneutic Reading of Aristotle on Credibility." The Ethos of Rhetoric. Ed. Michael J. Hyde. Columbia: University of South Carolina Press, 2004. Print.

Turner, Graeme. “Approaching Celebrity Studies.” Celebrity Studies 1.1 (2010): 11-20. DOI: 10.1080/19392390903519024

Von Burg, Ron, and Paul E. Johnson. "Yearning for a Past that Never Was: Baseball, Steroids, and the Anxiety of the American Dream. Critical Studies in Media Communication 26.4 (2009): 351-371. DOI: 10.1080/15295030903176641

West, Mark, and Chris Carey. "(Re)Enacting Frontier Justice: The Bush Administration's Tactical Narration of the Old West Fantasy after September 11." Quarterly Journal of Speech 92.4 (2006): 379-412. DOI: 10.1080/00335630601076326

Woodall, Bernie. "Clint Eastwood's 'Halftime' Ad Uses Chrysler Turnaround as Inspiration." The Huffington Post. 6 Feb. 2012. Web. 7 Feb. 2012. 